\title{
Evaluation of greenhouse rose cultivars in open field condition under Northern dry zone of Karnataka, India
}

\author{
G.B. Srinivasulu ${ }^{1 *}$, N. Jagadeesha ${ }^{2}$, D. P. Prakash ${ }^{3}$, N. Ashok ${ }^{4}$, \\ Gajanana Kustagi ${ }^{5}$ and Soujanya ${ }^{5}$
}

${ }^{1}$ Division of Floriculture and Land Scape Architecture, ${ }^{2}$ Division of Agronomy, College of Horticulture, ${ }^{3}$ Division of Horticulture, ${ }^{4}$ Division of Social Sciences, ${ }^{5}$ Division of Horticulture, College of Horticulture, Munirabad, University of Horticultural Sciences, Bagalkot, Karnataka, India

*Corresponding author

\section{Keywords}

Evaluation, cv. Pappai Red., cv.

Folk Lore.

Tineke,

Rose

Article Info

Accepted:

08 January 2020

Available Online:

10 February 2020

\section{A B S T R A C T}

A field experiment to evaluate eleven greenhouse rose cultivars was conducted at an experimental field of Department of Floriculture and Landscape Architecture, College of Horticulture, Munirabad (Koppal). Results revealed that there were significant cultivars among the varieties for growth, flowering and yield characters. Among the cultivars, maximum plant height $(95.67 \mathrm{~cm})$, number of branches (16.00), number of leaves (367.67) and plant spread $(42.75 \mathrm{~cm})$ was recorded in cv. Pappai Red. Among the cultivars cv.Tropical Amazon took less number of days (9.00 days) which was on par with Pappai Red (9.67 days) and Noblesse (9.67 days).Maximum flower diameter (8.67 $\mathrm{cm})$ was observed in cv. Folk Lore.Maximum stalk length $(43.23 \mathrm{~cm})$ was obtained in cv.Grand Gala which was on par with Pappai Red $(40.53 \mathrm{~cm})$ and Tajmahal $(38.73 \mathrm{~cm})$.Maximum number of flowers per plant (145.67) were recorded in cv. Folk Lore.Among the cultivars, maximum vase life (5.33 days) was observed in cv. Tineke which was on par with Pappai Red (4.67 days), Grand Gala (4.33) and Tajmahal (4.33 days).

\section{Introduction}

Roses, the "Queen of the Flowers," have been enjoyed for thousands of years. Their cultivation dates back to at least Greek and Roman times. Among cut flowers, Rose
(Rosa spp) has occupied a unique position both in beauty and trade. The Rosa genus belongs to the family Rosaceae with chromosome number $2 \mathrm{n}=4 \mathrm{x}=28$. The present day beautiful cultivars of exquisite shape, different sizes, bewitching colours and 
most delightful fragrance have made it an important flower crop. Rose ranks first among the top ten cut flowers in the International flower market. Among all other cut flowers, roses lead in popularity because of their beauty, fragrance and long lasting blooming qualities (Ghaffoor et al., 2000; Tabassum et al., 2002). It may be used for planting in rockeries, pots and for cut flower production. The heavy demand for rose cut flowers in the European markets is mainly from November to March due to the shortage of local production because of severe winter. Fortunately, this is the most congenial condition for successful production of most of the flowers, including roses in India.

The success of rose cultivation however, depends on proper choice of type and cultivars of roses. The majority of cut flower roses are grown in climate-controlled polyhouses where temperature, moisture and light can be adjusted to produce flowers at periods of peak demand. Some varieties of roses are successfully grown in our country under open conditions for cut flower and loose flower purposes. However, a limited research work is done to know the performance of outdoor rose cultivars. The cultivation of rose is gaining importance in Karnataka due to its relative ease in cultivation, high returns, increasing market demand and high communication facilities. The performance of greenhouse cultivars under open condition is not known and there is great potentiality to evaluate their performance in open field conditions to know their suitability.

\section{Materials and Methods}

The study was carried out in the experimental field of Department of Floriculture and Landscape Architecture, College of Horticulture, Munirabad (Koppal), during the year 2014- 15 in Randomized Complete
Block Design involving 11 cultivars of rose with three replications. The cultivars which were included, viz., Carvetti, Grand Gala, Folk Lore, TinikeGold Strike, Pappai Red, Tropical Amazon, Noblesse, Tajmahal, Bugati andRavelti,were planted at a spacing of $60 \mathrm{~cm} \times 60 \mathrm{~cm}$. The crop was raised by following standard cultural practices (Anon, 2014). The data was recorded on plant height $(\mathrm{cm})$, Number of branches per plant, Number of leaves per plant, Plant spread $(\mathrm{cm})$, Time taken from emergence of flower bud to harvest, Flower diameter $(\mathrm{cm})$, Length of flower stalk $(\mathrm{cm})$, Number of flowers per plant, vase life (days).

\section{Results and Discussion}

Plant height varied significantly among the cultivars, maximum plant height was observed in the cultivar Pappai $\operatorname{Red}(95.67$ $\mathrm{cm})$. The minimum plant height $(70.00 \mathrm{~cm})$ was recorded in the Tinike. Variations for plant height is a varietal character. Similar variations in plant height was reported by Lundstad (1975), Kanamadi and Patil (1993) and Behera et al. (2002).

Maximum number of branches per plant (16.00) was recorded in cv. Pappai Red which was on par with Folk Lore (15.67) and Grand Gala (14.00). However, minimum number of branches per plant was recorded in Carvetti(8.67). The maximum number of leaves was recorded in cv. Pappai Red (367.67) which was on par with Tajmahal (357.33) and Grand Gala (356.00). The number of leaves were minimum in cv. Folk Lore (307.00). This difference might be due to varietal character and plant structure. This was in accordance with findings of Bhattacharjee et al. (1993), Chandrashekar (1993) and Dias and Patil (2003).

Among the cultivars maximum plant spread was recorded in cv. Pappai Red (42.75) which 
was on par with Grand Gala $(40.93 \mathrm{~cm})$ and Folk Lore $(39.17 \mathrm{~cm})$. However, it was minimum in cv. Gold Strike $(26.20 \mathrm{~cm})$. The variation in plant spread may be due to varietal differences. This was in accordance with the findings of Chandrashekaraih (1973), Dias and Patil (2003) and Sharma and Sharma (2003).

Significant differences were obtained among the cultivars with respect to days taken from emergence of flower bud to harvest. Among the cultivarscv.Tropical Amazon took less number of days (9.00 days) which was on par with Pappai Red (9.67 days) and Noblesse (9.67 days). Whereas cv. Tineke took maximum days (13.67) for harvest. Similar variation with respect to days taken from emergence of flower bud to harvestwas reported by Chandrashekaraiah (1973) in rose. The variation among the varieties for different flowering characters may be due to differences in the inherent make up of these varieties.

Flower diameter of fully opened flower $(\mathrm{cm})$ differed significantly among the different cultivars. Maximum flower diameter (8.67 $\mathrm{cm}$ ) was observed in Folk Lore which was on par with Grand Gala (8.21) and Tajmahal (8.17). Whereas, the minimum flower diameter $(6.06 \mathrm{~cm})$ was recorded in Carvetti(6.43). The variation in flower diameter is mainly due to genetic make-up of the individual cultivar. Similar variations in flower diameter were obtained by Murugesan et al. (1991)Verma et al. (2008) and Polara et al. (2004).

Flower stalk length differed significantly among different cultivars. Maximum stalk length $(43.23 \mathrm{~cm})$ was obtained in cv. Grand Gala which was on par with Pappai Red $(40.53 \mathrm{~cm})$ and Tajmahal $(38.73 \mathrm{~cm})$. Whereas, the minimum stalk length (16.93 $\mathrm{cm})$ was observed in cv. Gold Strike. Difference in stalk length might be due to varietal characteristics of the varieties. Similar results while evaluating varieties for stalk length have been reported previously by Murugesan et al. (1991), Bhattacharjee et al. (1993) and Sundaram et al. (1996).

Table.1 Yield and quality parameters of different greenhouse rose cultivars

\begin{tabular}{|l|c|c|c|c|}
\hline Cultivars & $\begin{array}{c}\text { Plant } \\
\text { height(cm) }\end{array}$ & $\begin{array}{c}\text { Number of } \\
\text { branches }\end{array}$ & $\begin{array}{c}\text { Number of } \\
\text { leaves }\end{array}$ & $\begin{array}{c}\text { Plant spread } \\
\text { (cm) }\end{array}$ \\
\hline Corvette & 71.00 & 8.67 & 259.33 & 29.50 \\
\hline Grand Gala & 84.33 & 14.00 & 356.00 & 40.93 \\
\hline Folklore & 88.67 & 15.67 & 307.00 & 39.17 \\
\hline Tineke & 70.00 & 12.00 & 355.33 & 37.15 \\
\hline Gold Strike & 79.00 & 11.33 & 261.33 & 26.20 \\
\hline Papai Red & 95.67 & 16.00 & 367.67 & 42.75 \\
\hline Tropical Amazon & 75.33 & 12.00 & 269.67 & 31.00 \\
\hline Noblesse & 76.67 & 11.67 & 321.00 & 29.30 \\
\hline Tajmahal & 84.67 & 13.00 & 357.33 & 38.12 \\
\hline Bugatti & 76.00 & 12.00 & 296.33 & 32.50 \\
\hline Ravel & 78.67 & 12.67 & 286.67 & 34.93 \\
\hline \multicolumn{1}{|c|}{ S.Em } & 4.67 & 0.86 & 20.36 & 2.16 \\
\hline CD $(\mathbf{P = 0 . 0 5 )}$ & 13.76 & 2.53 & 60.05 & 6.37 \\
\hline
\end{tabular}


Table.2 Yield and quality parameters of different greenhouse rose cultivars

\begin{tabular}{|l|c|c|c|c|c|}
\hline \multicolumn{1}{|c|}{ Cultivars } & $\begin{array}{c}\text { Days taken from } \\
\text { emergence of } \\
\text { flower bud to } \\
\text { harvest }\end{array}$ & $\begin{array}{c}\text { Diameter of fully } \\
\text { opened flower } \\
\text { (cm) }\end{array}$ & $\begin{array}{c}\text { Stalk } \\
\text { length } \\
\text { (cm) }\end{array}$ & $\begin{array}{c}\text { Number of } \\
\text { flowers / plant } \\
\text { /1st year }\end{array}$ & $\begin{array}{c}\text { Vase life } \\
\text { (days) }\end{array}$ \\
\hline Corvette & 10.67 & 6.43 & 29.93 & 75.67 & 3.33 \\
\hline Grand Gala & 11.00 & 8.21 & 43.23 & 138.00 & 4.33 \\
\hline Folklore & 11.67 & 8.67 & 27.53 & 145.67 & 2.67 \\
\hline Tineke & 13.67 & 7.75 & 29.67 & 97.33 & 5.33 \\
\hline Gold Strike & 10.33 & 7.57 & 16.93 & 79.67 & 3.67 \\
\hline Papai Red & 9.67 & 8.13 & 40.53 & 134.67 & 4.67 \\
\hline Tropical Amazon & 9.00 & 6.91 & 18.37 & 71.00 & 3.00 \\
\hline Noblesse & 9.67 & 6.70 & 20.90 & 103.67 & 3.33 \\
\hline Tajmahal & 11.33 & 8.17 & 38.73 & 135.00 & 4.33 \\
\hline Bugatti & 13.33 & 7.56 & 33.07 & 83.60 & 3.33 \\
\hline Ravel & 11.67 & 6.80 & 24.73 & 94.67 & 2.67 \\
\hline S.Em & 0.57 & 0.46 & 2.20 & 6.36 & 0.41 \\
\hline CD (P=0.05) & 1.70 & 1.37 & 6.49 & 18.75 & 1.21 \\
\hline
\end{tabular}

Yield of a crop is the ultimate of what all is done to the crop to achieve same. Yield depends on the growth of the crop and the conditions prevailed during the cropping period.Maximum number of flowers per plant (145.67) were recorded in cv. Folk Lorewhich was on par with Grand Gala (138.00) and Tajmahal (135.00). The least number offlowers per plant (71.00) were observed inTropical Amazon.The favourable growing environment and climatic factors have also contributed for expressing their maximum yield potential in high yielding varieties (Betonia, 1996, Praneethaet al. 2002 and Talia et al. 2003).

The vase life of rose flowers under room temperature showed significant differences. Among the cultivars, maximum vase life (5.33 days) was observed in cv. Tinekewhich was on par with Pappai Red (4.67 days), Grand Gala (4.33) and Tajmahal (4.33 days). Whereas, the minimum vase life (2.67 days) was observed in cvs. Folk Lore and Ravel.

\section{References}

Anonymous, (2014). Package of practices, Horticultural crops, University of Horticultural Sciences, Bagalkot.

Behera, T. K., Sirohi, P. S. and Pal, A., 2002, Assessment of chrysanthemum germplasm for commercial cultivation under Delhi condition. J. Orn. Hort., New series 5 (2): 11-14.

Betonia, G.L., 1996, Germplasm collection and evaluation of different anthurium cultivars. J. Crop Sci.,20: 12.

Bhattacharjee, S. K., Singh, V. C. and Saxena, N. K., 1993, Studies on vegetative growth, flowering, flower quality and vase life of roses. Singapur J. Primary Industries, 21(2): 67-71.

Chandrashekar, 1993, Evaluation of rose varieties for cut flower production under Northern transitional tract of Karnataka. M. Sc. (Agri.)thesis submitted to UAS, Dharwad.

Chandrashekaraiah, T. S., 1973, Studies on evaluation of the hybrid tea roses for cut 
flowers. M. Sc. (Agri.) thesis submitted to UAS, Bangalore.

Dias, S. M. F. and Patil, A. A., 2003, Performance of elite rose varieties at different population levels under transitional tract of Karnataka. J. Agric. Sci., 16(2): 271-275.

Ghaffoor, A., Shaheen, M., Iqbal M., Waseem K. and Nadeem, 2000. Impact of various combinations of NPK on the growth, yield and quality parameters of rose.Pak. J. Biol.3:1560-1562.

Kanamadi, V. C. and Patil, A. A., 1993, Evaluation of eight rose cultivars under Northern Transitional tracts of Karnataka. The Indian Rose Annual, 11:139-142.

Lundstad, A., 1975, Cultivar testing of floribunda roses, 1969-1972. Forsk. Fors. Landr., 26 (2) : 233-244.

Murugesan, S., Thamburaj, S. and Ramani, K., 1991, Performance of rose cultivars at Yercaud. South Indian Hort., 39: 359362.

Polara, N. D., Viradia, R. R. and Khimani, R. A., 2004, Evaluation pf different rose cultivars in summer under south Saurashtra condition. J.Orn. Hort.,7(3-4):
102-105.

Praneetha, S., Jawaharlal, M. and Vijayakumar, M., 2002, Performance of anthurium under shadenet condition at Yercaud. J.Orn. Hort., 328-329.

Sharma, A. and Sharma, S. K., 2003, Scoring technique for rose evaluation. J. Orn. Hort., New series, 6(1): 50-54.

Sundaram, K.S., Rajamani, K., Rengasmy, P. and Azhakiamanavalan, R.S., 1996, Studies on the performance of hybrid tea rose cultivars. South Indian Hort., 44(3/4): 83-84.

Tabassum, R., Ghaffoor, A., Waseem K. and Nadeem, M. A., 2002. Evaluation of Rose cultivars as cut flower production. Asi. J. Plant Sci. 1(6): 668-669.

Talia, M.A.C., Cristiano, G., Forleo, L.R., Lipari, V., Noto, G. and Leonardi, C., 2003, Evaluation of new anthurium cultivars in soilless culture. ActaHort., 614: 223-226.

Verma, S., Kumar, S. and Deepti, S., 2008, Studies on variability for various quantitative traits in rose (Rosa spp.). J.Orn. Hort., 11(1): 62-65.

\section{How to cite this article:}

Srinivasulu, G.B., N. Jagadeesha, D. P. Prakash, N. Ashok, Gajanana Kustagi and Soujanya. 2020. Evaluation of greenhouse rose cultivars in open field condition under Northern dry zone of Karnataka, India. Int.J.Curr.Microbiol.App.Sci. 9(02): 1640-1644. doi: https://doi.org/10.20546/ijcmas.2020.902.188 